\title{
ANALISIS FAKTOR-FAKTOR YANG MEMPENGARUHI PRODUKSI INDUSTRI PENGOLAHAN DAN EFISIENSI PRODUKSI PADA KABUPATEN/KOTA DI JAWA TENGAH TAHUN 2010-2015
}

\author{
Setyo Adi Wibowo \\ Program Studi Magister Ilmu Ekonomi dan Studi Pembangunan \\ Fakultas Ekonomika dan Bisnis Universitas Dipenogoro \\ E-mail: setyo.wibowo191@gmail.com \\ Nugroho SBM \\ Department of Economics, Diponegoro University \\ Email: nugroho.sbm@gmail.com
}

Received: May 2018; Accepted: July 2018; Available online: July 2018

\begin{abstract}
Abstrak
Analisis faktor-faktor produksi industri pengolahan menjadi aspek penting dalam meningkatkan nilai tambah antar sektor dan berkontribusi besar pada sektor PDRB dalam pembangunan ekonomi regional. Kerjasama antar daerah dapat memicu terkonsentrasinya industri pengolahan atau aglomerasi industri di wilayah Jawa Tengah. Daerah yang berpotensi memiliki SDA sebagai sumber bahan baku dan SDM yang terampil dapat memperoleh manfaat skala ekonomi, lokasi ekonomi, dan tenaga kerja yang berdekatan guna mendorong pertumbuhan ekonomi regional. Pengunaan input-input dalam proses produksi menganggap subtitusi faktor-faktor produksi dapat dioptimalkan dan elastisitas subtitusinya adalah 1. Pengukuran efisiensi produksi dengan cara efisiensi teknis, efisiensi harga, efisiensi ekonomi dan return to scale. Tujuan penelitian ini menganalisis pengunaan input-input produksi dan menambahkan faktor eksogen yaitu aglomerasi industri. Metode analisis menggunakan pendekatan Stochastic Frontier Analysis (SFA) dengan estimasi program Frontier 4.1. Hasil penelitian modal $\left(\mathrm{X}_{1}\right)$, bahan baku $\left(\mathrm{X}_{3}\right)$, tenaga kerja $\left(\mathrm{X}_{3}\right)$, upah per tenaga kerja $\left(\mathrm{X}_{4}\right)$, aglomerari (AG) memiliki pengaruhi positif signifikan. Kesimpulan penambahan faktor produksi secara proporsional untuk mencapai skala hasil produksi yang optimal. Pembaharuan mesin-mesin produksi menghadapi perkembangan teknologi modern dalam meningkatkan hasil produksi. Meningkatkan kualitas SDM melalui pelatihan dan pendidikan formal sehingga bersifat padat karya (labor intensive) untuk menyerap banyak tenaga kerja.
\end{abstract}

Kata Kunci : Industri Pengolahan; Aglomerasi Industri; Produksi Industri; Efisiensi

\begin{abstract}
Analysis of the factors of production of processing industry becomes an important aspect in increasing the added value between sectors and contribute greatly to the sector GRDP in regional economic development. Inter-regional cooperation can trigger the concentration of processing industry or industrial agglomeration in central java region. Areas with the potential to have SDA as a source of raw materials and skilled human resources can benefit economies of scale, economic location, and adjacent labor force to promote regional economic growth. The use of inputs in the production process assumes the substitution of the factors of production can be optimized and the elasticity of the subtitute is 1. Measurement of production efficiency by means of technical efficiency, price efficiency, economic efficiency and return to scale. The purpose of this research is to analyze the use of production inputs and add exogenous factor that is industrial agglomeration. The analysis method used Stochastic Frontier Analysis (SFA) approach with Frontier 4.1 program estimation. Methods The results of capital research (X1), raw materials (X3), labor (X3),
\end{abstract}


wages per labor (X4), agglomerari (AG) have significant positive effects. The conclusion of adding factor of production proportionally to achieve optimal production scale. Renewal of production machinery is facing the development of modern technology in improving production. Improving the quality of human resources through training and formal education so that it is labor intensive to absorb a lot of manpower.

Keywords: Processing Industry; Industrial Agglomeration; Industrial Production; Efficiency.

How to Cite: Wibowo, S. A., SBM, N. (2018). Analisis Faktor-Faktor yang Mempengaruhi Produksi Industri Pengolahan dan Efisiensi Produksi pada Kabupaten/Kota di Jawa Tengah Tahun 2010-2015. Media Ekonomi dan Manajemen, 33(2), 205213.

\section{PENDAHULUAN}

Menurut Kuncoro (2012), industrialisasi mengalami perkembangan secara bertahap yang membawa perubahan struktur sektor ekonomi yaitu terjadinya penurunan kontribusi sektor pertanian dan meningkatnya sektor industri pengolahan. Sektor industri pengolahan dapat meningkatkan nilai tambah sektor lain dalam menyerap tenaga kerja guna peningkatan pembangunan ekonomi daerah. Kontribusi 17 sektor PDRB provinsi Jawa Tengah pada tahun 20102015 di jelaskan pada Gambar 1.

\begin{tabular}{|c|c|c|}
\hline 工 & Jasa Lainnya & \multirow{2}{*}{ — 2010} \\
\hline$\underline{0}$ & Jasa Kesehatan dan.. & \\
\hline$n$ & Jasa Pendidikan & 2011 \\
\hline$\Xi$ & Administrasi.. & 2012 \\
\hline$m$ & Jasa Perusahaan & 2013 \\
\hline$\simeq$ & Real Estate & \multirow{2}{*}{ - 2014} \\
\hline 二 & Jasa Keuangan dan.. & \\
\hline$\stackrel{0}{ }$ & Informasi dan.. & \multirow[t]{7}{*}{2015} \\
\hline$a$ & Penyediaan.. & \\
\hline$\infty$ & Transportasi dan.. & \\
\hline r & Perdagangan Besar.. & \\
\hline 6 & Kontruksi & \\
\hline$n$ & PengadaanAir,Pengo.. & \\
\hline$\nabla$ & Pengadaan Listrik.. & \\
\hline$m$ & Industri Pengolahan & \\
\hline $\mathrm{N}$ & Pertambangan dan.. & \\
\hline- & Pertanian,Kehutanan.. & \\
\hline
\end{tabular}

Sumber : BPS Jawa Tengah, 2018

Gambar 1. PDRB Provinsi Jawa Tengah Tahun 2010-2015 (Miliar Rupiah)
Menurut Sjafrizal (2008), Negara memiliki satu atau lebih pusat-pusat pertumbuhan ekonomi regional yang berdampak positif di wilayah region yang memiliki potensi kuat akan merembet kewilayah region-region yang lemah (trickle down effect) dan menghasilkan produk komplementer.

Menurut Kuncoro (2012), proses produksi yang terjadi dalam kerjasama antar daerah dapat memicu terkonsentrasinya industri atau aglomerasi industri yang berpotensi memperoleh manfaat skala ekonomi, lokasi, dan tenaga kerja sejalan dalam mendorong pertumbuhan ekonomi regional.

Menurut Suryanto (2012), perusahaan asing mengalami pertumbuhan produktivitas yang lebih besar daripada perusahaan lokal. Dalam penelitian Romdhoni (2015), tenaga kerja manufaktur lebih berpengaruh dari tenaga kerja nonmanufaktur dalam pembentukan output industri dan faktor modal berpengaruh negatif. Dan penelitian Riyardi (2015), industri tidak menikmati kemajuan teknologi karena industri yang bersifat penanaman modal asing (PMA). Kemajuan teknologi industri yang bersifat penanaman modal dalam negeri (PMDN) bersifat padat karya mengalami masalah di kualitas SDM yang rendah dan tidak memperhatikan teknologi modern.

Berdasarkan latar belakang di atas perlu dilakukan analisis faktor-faktor yang mempengaruhi produksi industri pengolahan dan efisiensi produksi pada kab/kota di provinsi Jawa Tengah. Bertujuan mengoptimalkan penggunaan faktor-faktor produksi industri pengolahan lebih baik 
dengan menggunakan pendekatan Stochastic Frontier Analysis.

\section{TELAAH PUSTAKA}

\section{Industrialisasi}

Menurut Arsyad (2010), proses modernisasi ekonomi mencakup seluruh sektor ekonomi yang mempunyai nilai tambah (added value) akan memacu sektor-sektor lain sehingga meningkatkan pendapatan regional. Proses pembangunan ekonomi jangka panjang dengan laju pertumbuhan ekonomi regional yang tinggi serta berkelanjutan dapat meningkatkan penyerapan tenaga kerja dan pendapatan masyarakat serta berkontribusi peningkatan PDRB.

\section{Faktor-Faktor Yang Mempengaruhi Industri Pengolahan}

Menurut Soekartawi (2003), faktor produksi diartikan sebagai unsur-unsur yang digunakan dalam proses produksi. Faktor-faktor produksi yang umumnya digunakan adalah modal produksi, bahan baku produksi, tenaga kerja produksi, upah per tenaga kerja produksi dan aglomerasi industri. Kegiatan produksi adalah kegiatan yang melakukan proses, pengolahan, dan mengubah faktor-faktor produksi industri pengolahan menjadi nilai manfaat yang lebih dan memiliki nilai tambah secara ekonomi.

\section{Modal produksi $\left(\mathrm{X}_{1}\right)$}

Menurut Riyanto (2001), modal produksi dapat diartikan barang atau uang yang digunakan untuk menghasilkan barang produksi atau hasil produksi. Modal yang digunakan untuk membiayai proses produksi secara keseluruhan memiliki pengaruh dari proses hasil produksi industri pengolahan.

\section{Bahan baku produksi $\left(\mathrm{X}_{2}\right)$}

Menurut Kholmi (2003), bahan baku produksi yang diolah dalam proses produksi merupakan bahan utama kegiatan produksi industri. Proses produksi penggunaan bahan baku akan berdampak pada penjualan dalam kenaikan harga dan akan berhenti berproduksi jika tidak tersedia.

\section{Tenaga Kerja Produksi $\left(\mathrm{X}_{3}\right)$}

Menurut Kusnendi (2003), tenaga kerja merupakan salah satu faktor penting dalam kegiatan produksi. Tenaga kerja terdiri dari dua kelompok, yaitu angkatan kerja dan bukan angkatan kerja.

\section{Upah Per Tenaga Kerja Produksi $\left(\mathrm{X}_{4}\right)$}

Menurut Simanjuntak (2011), upah adalah imbalan yang diterima per pekerja atas jasa kerja yang diberikannya dalam proses produksi barang atau jasa di industri. Upah tenaga kerja produksi berfungsi sebagai keberlangsungan hidup yang layak bagi kemanusiaan dan produksi yang dinyatakan dalam bentuk uang yang ditetapkan menurut suatu persetujuan, undang-undang, peraturan, dan dibayarkan atas suatu dasar perjanjian kerja antara pemimpin industri dengan tenaga kerja.

\section{Aglomerasi Industri (AG)}

Menurut Kuncoro (2012), pada saat aglomerasi di suatu wilayah mampu mencapai skala ekonomis maksimum maka ekspansi setelah titik tersebut hanya akan menimbulkan dampak negatif (agglomeration diseconomies) bagi wilayah aglomerasi. Terjadinya aglomerasi industri mempunyai keuntungan-keuntungan tertentu yaitu skala ekonomis (produksi dalam jumlah besar) dan keuntungan penghematan biaya yaitu : 1.) Keuntungan Internal Industri Pengolahan; 2.) Keuntungan Lokalisasi (Localization Economies); 3.) Keuntungan Ekstern (keuntungan urbanisasi). Munculnya agglomeration economies di suatu wilayah akan mendorong pertumbuhan ekonomi di wilayah tersebut karena terciptanya efisiensi produksi.

Menurut Sbergami (2002), aglomerasi dapat diukur dengan beberapa cara dengan proporsi jumlah tenaga kerja sektor industri di kabupaten/kota terhadap jumlah 
tenaga kerja sektor industri dalam suatu provinsi.

Indeks Ballasa.: $\frac{\frac{E i j}{\Sigma j E i j}}{\frac{\Sigma i E i j}{\Sigma i \Sigma j E i j}} \ldots \ldots \ldots \ldots . . . .$.

Keterangan :

$E i j=$ Total tenaga kerja pada sektor industri tingkat kabupaten/kota; $\Sigma j E i j=$ Total tenaga kerja tingkat kabupaten/kota; $\Sigma j E i j=$ Total tenaga kerja pada sektor industri provinsi; $\Sigma i \Sigma j E i j=$ Total tenaga kerja tingkat provinsi.

\section{Fungsi Produksi}

Menurut Soekartawi (2003), pengukuran fungsi produksi dengan menggunakan pendekatan stochastic frontier mengasumsikan fungsi produksi ditransformasikan ke dalam bentuk linier logaritma natural (ln) maka produksi industri pengolahan (manufaktur) dapat dituliskan dengan persamaan model regresi produksi industri pengolahan (manufaktur):

$\mathrm{LnY}=\beta_{0}+\beta_{1} \operatorname{LnX}_{1}+\beta_{2} \operatorname{LnX}_{2}+\beta_{3} \operatorname{LnX}_{3}+$ $\beta_{4} \operatorname{LnX}_{4}$

\section{Fungsi Produksi Frontier}

Menurut Soekartawi (2003), fungsi produksi frontier mewakili penggunaan faktor-faktor yang mempengaruhi produksi industri pengolahan (manufaktur) secara luas. Model fungsi produksi frontier yang digunakan untuk mengukur proses produksi industri pengolahan (manufaktur) yang dinyatakan sebagai berikut :

$Y=f\left(\mathrm{X}_{\mathrm{i}} \beta\right) \exp \varepsilon_{i}$

Dimana :

$\beta=$ Parameter yang akan dihitung.

$\mathrm{X}_{\mathrm{i}}=$ Input faktor-faktor yang mempengaruhi produksi industri pengolahan.

$\varepsilon_{\mathrm{i}}=v_{\mathrm{i}}+u_{\mathrm{i}}$

Menurut Soekartawi (2003),

produksi frontier stochastic adalah $f$ $(X) \exp \varepsilon_{i}$ mempunyai beberapa distribusi symmetris untuk menangkap pengaruh random dari kesalahan pengukuran dan gangguan eksogenus yang menyebabkan penempatan inti deterministic $f(X)$ untuk beragam antar industri pengolahan (manufaktur). Inefisensi teknis relative terhadap produksi frontier stochastic kemudian ditangkap oleh komponen 1 (satu) sisi $\exp (-u), u \geq 0$.

\section{Pengukuran Pendekatan Stochastic Frontier Analysis (SFA)}

Menurut Soekartawi (2003), pengukuran dengan statistik ada dua metode pengukuran yang umum digunakan yaitu metode non-parametrik dan parametrik. Metode parametrik meliputi Stochastic Frontier Analysis (SFA) untuk menghitung efisiensi produksi industri pengolahan (manufaktur). Pendekatan dengan pengukuran parametrik memiliki keunggulan dengan frontier stochastic yang melibatkan disturbance term mewakili gangguan atau kesalahan dalam pengukuran dan faktor eksogen yang berada diluar kontrol faktor-faktor yang mempengaruhi proses produksi.

Menurut Soekartawi (2003), terdapat 2 bentuk error term dalam hal ini $v$ mewakili random error yang tidak terkait dengan inefisiensi. Sedangkan $u$ mewakili inefisiensi dalam pengukuran metode stochastic frontier menggunakan kedua asumsi tersebut dan diasumsikan menjadi independen and identically distribution (iid).

Inefficiency $=1-\exp \left(-U_{\mathrm{i}}\right)$

Menurut Soekartawi (2003), secara konvensional komponen random error diasumsikan terdistribusi normal. Asumsi distribusi komponen inefisiensi atau variable acak non-negatif dapat dianggap sebagai model setengah normal, model eksponensial, model yang normal terpotong dan model gamma rincian teknis berkaitan dengan distribusi.

\section{Efisiensi Teknis (ET)}

Menurut Soekartawi (2003), efisiensi teknis adalah suatu penggunaan faktorfaktor produksi dikatakan efisien secara teknis jika faktor-faktor produksi yang dipakai menghasilkan produksi yang maksimum. Rasio dari observasi output produksi untuk industri pengolahan (manufaktur) ke-i relative terhadap output 
potensial produksi yang didefinisikan oleh fungsi frontier dari faktor input produksi yang tersedia. $\mathrm{X}_{\mathrm{i}}$ yang digunakan untuk mendefinisikan efisiensi teknis dari industri pengolahan (manufaktur) ke-i adalah sebagai berikut :

$\mathrm{ET}_{\mathrm{i}}=\frac{Y i}{\exp (X i \beta)}=\frac{\exp (X i \beta-u i)}{\exp (X i \beta)}=\exp (-u i)(2.5)$

\section{Efisiensi Harga (EH)}

Menurut Soekartawi (2003), efisiensi harga menunjukkan hubungan biaya produksi dan output produksi. Efisiensi harga dapat tercapai jika dapat memaksimumkan keuntungan yaitu menyamakan produksi marginal setiap faktor-faktor produksi dengan harga produksi. Efisiensi harga dapat tercapai jika nilai dari produksi marginal sama dengan harga faktor-faktor produksi yang bersangkutan. Tingkat efisiensi harga dapat dihitung dengan menggunakan persamaan sebagai berikut:

$\mathbf{E H}_{\mathrm{i}}=\frac{Y i}{\exp (X i \beta)}=\frac{Y i}{Y o p t}$

Artinya bahwa efisiensi harga adalah tingkat perbandingan antara output produksi Yi dengan output produksi optimal Yopt.

\section{Efisiensi Ekonomi (EE)}

Menurut Soekartawi (2003), efisiensi ekonomi adalah kondisi proses produksi yang menggunakan input produksi dan biaya produksi seminimal mungkin sehingga mampu menghasilkan sejumlah output produksi tertentu atau dengan menggunakan input produksi dan biaya produksi tertentu mampu menghasilkan output maksimal industri pengolahan (manufaktur).

$E E=E T X E H$

Dimana $: \mathrm{EE}=$ Efisiensi Ekonomi; ET = Efisiensi Teknis; EH = Efisiensi Harga.

\section{Return To Scale (RTS)}

Menurut Soekartawi (2003), return to scale (RTS) atau keadaan skala usaha perlu diketahui guna melihat kombinasi penggunaan faktor produksi. Terdapat tiga kemungkinan dalam nilai return to scale, yaitu :

\section{Decreasing returns to scale}

bila $\left(b_{1}+b_{2}+\ldots .+b n\right)<1$. Dalam keadaan demikian, dapat diartikan bahwa proporsi penambahan faktor produksi melebihi penambahan produksi.

2. Constant return to scale

Bila $\left(b_{1}+b 2+\ldots .+b n\right)=1$. Dalam keadaan demikian, dapat diartikan bahwa proporsi penambahan faktor produksi akan proporsional dengan penambahan produksi.

3. Increasing return to scale

Bila $\left(b_{1}+b_{2}+\ldots .+b_{n}\right)>1$. Dalam keadaan demikian, maka dapat diartikan bahwa proporsi penambahan faktor produksi akan menghasilkan produksi yang lebih besar.

\section{Ekonomi Regional}

Menurut Jhingan (2008), pembangunan yang terjadi di suatu tempat merupakan suatu daya tarik bagi pembangunan ekonomi di daerah sehingga akan terjadi konsentrasi pembangunan pada wilayah tersebut. Konsentrasi tersebut disebabkan oleh potensi faktorfaktor di daerah pusat pertumbuhan yang kuat dipengaruhi sekaligus menghambat pembangunan di wilayah sekitarnya yang disebut dengan efek polarisasi atau pemusatan.

\section{METODE PENELITIAN Jenis dan Sumber Data}

Penelitian ini menggunakan data sekunder yang berupa data panel dengan periode pengamatan tahun 2010 - 2015 (6 tahun) dari Statistik Industri Besar dan Sedang Volume I yang diterbitkan oleh BPS Jawa Tengah. 
Analisis Data

Menurut Soekartawi (2003), pengukuran fungsi produksi dengan menggunakan pendekatan stochastic frontier mengasumsikan fungsi produksi ditransformasikan ke dalam bentuk linier logaritma natural (ln) yaitu sebagai berikut:

$\mathrm{LnY}=\beta_{0}+\beta_{1} \operatorname{LnX}_{1}+\beta_{2} \operatorname{LnX}_{2}+\beta_{3} \operatorname{LnX}_{3}+$ $\beta_{4} \operatorname{LnX}_{4}$

Jumlah output produksi industri pengolahan $(\mathrm{Y})$ dipengaruhi oleh modal produksi $(\mathrm{K})$, bahan baku produksi (BB), tenaga kerja produksi (L), upah per tenaga kerja produksi (U) dan $\varepsilon_{\mathrm{i}}$ adalah kesalahan atau error (disturbance term). Dalam mengoptimalkan penggunaan faktor-faktor yang mempengaruhi produksi dan efisiensi industri pengolahan (manufaktur).

\section{HASIL PENELITIAN}

\section{Regresi Fungsi Produksi}

Hasil regresi data panel dengan menggunakan pendekatan Fixed Effect Model (FEM).

Tabel 1. Hasil Regresi Variable Yang Mempengaruhi Produksi Industri

\begin{tabular}{lcccc}
\hline Variabel & Coefficient & Std. Error & t-Statistic & Prob. \\
\hline \hline LOG(K) & 0.040366 & 0.007680 & 5.256301 & 0.0000 \\
LOG(B) & 0.632026 & 0.025843 & 24.45594 & 0.0000 \\
LOG(L) & 0.398313 & 0.064402 & 6.184816 & 0.0000 \\
LOG(U) & 0.346151 & 0.025576 & 13.53405 & 0.0000 \\
\hline
\end{tabular}

Sumber : Eviews 9.1, 2018(diolah)

\section{Deteksi Penyimpangan Asumsi Klasik Deteksi Multikolonieritas}

Tidak terdapat hubungan antar variabel bebas yang memiliki nilai lebih dari 0,8 . Oleh sebab itu, dapat disimpulkan terbebas dari multikolonieritas yang cukup mengganggu.

Tabel 2. Tabel Residual Correlation

\begin{tabular}{lllll}
\multicolumn{5}{c}{ Matrix } \\
& LOG(K) & LOG(B) & LOG(L) & LOG(U) \\
\hline \hline LOG(K) & 1.000000 & 0.666845 & 0.631801 & 0.315572 \\
LOG(B) & 0.666845 & 1.000000 & 0.540241 & 0.407709 \\
LOG(L) & 0.631801 & 0.540241 & 1.000000 & 0.155925 \\
LOG(U) & 0.315572 & 0.407709 & 0.155925 & 1.000000 \\
\hline
\end{tabular}

Sumber : Eviews 9.1, 2018(diolah)

\section{Deteksi Autokolerasi}

Pada hasil regresi nilai DurbinWatson yaitu 2.0607 dengan $\mathrm{n}=210$ maka diperoleh nilai Durbin-Watson pada tabel dengan tingkat alpha sebesar $5 \%$ yaitu dL $=1,7176$ dan $\mathrm{dU}=1,8199,4-\mathrm{dU}=2,1801$ dan 4-dL = 2,2824. Hasil deteksi autokorelasi menunjukkan bahwa nilai Durbin-Watson berada pada keputusan menerima Ho atau tidak ada autokorelasi baik positif maupun negatif.

\section{Deteksi Heteroskedastisitas}

Semua variabel memiliki nilai probabilitas di atas tingkat signifikansi 5\% $(0,05)$. Oleh sebab itu, dapat disimpulkan bahwa model dalam penelitian ini telah terbebas dari penyakit heteroskedastisitas.

\section{Deteksi Normalitas}

Nilai probabilitas Jarque-Bera adalah 0,150 yang berarti lebih besar dari taraf nyata $5 \%(0,05)$ maka dapat disimpulkan bahwa residual terdistribusi normal.

\section{Uji Korelasi}

Berdasarkan dari perbandingan antara nilai r-hitung sebesar 0.6804 lebih besar dari r-tabel sebesar 0.33 dengan tingkat nyata sebesar $0,05(\alpha=5 \%)$. Hasil menunjukan bahwa variabel Aglomerasi (AG) industri pengolahan berpengaruh positif dan signifikan terhadap variabel output produksi $(\mathrm{Y})$.

\section{Efisiensi Produksi}

Pengukuran efisiensi produksi industri dibagi menjadi efisiensi teknis, efisiensi harga, efisiensi ekonomi dan return to scale dapat dijelaskan pada Tabel 3. 
Tabel 3. Hasil Estimasi Efisiensi Produksi

\begin{tabular}{clcc}
\multicolumn{4}{c}{$(S F A)$} \\
\hline No & \multicolumn{1}{c}{ Variabel } & Koefisien & T-Ratio \\
\hline 1 & Konstanta & 0.11 & 0.277 \\
2 & $\mathbf{X}_{\mathbf{1}}$ & 0.17 & 0.188 \\
3 & $\mathbf{X}_{\mathbf{2}}$ & 0.87 & 0.323 \\
4 & $\mathbf{X}_{\mathbf{3}}$ & 0.14 & 0.311 \\
5 & $\mathbf{X}_{\mathbf{4}}$ & 0.32 & 0.678 \\
6 & Efisiensi Teknis & 0.95 & \\
7 & Inefisiensi & 0.05 & \\
8 & Efisiensi Harga & 0.38 & \\
9 & Efisiensi Ekonomi & 0.35 & \\
10 & Return to scale & 1.61 & \\
11 & $\mathbf{N}$ & 210 & \\
\hline
\end{tabular}

Sumber: Frontier 4.1, 2018 (diolah)

\section{Efisiensi Teknis (ET)}

Rata-rata efisiensi teknis kab/kota di provinsi Jawa Tengah dari tahun 20102015 yaitu sebesar 0,95 .

\section{Efisiensi Harga (EH)}

Dari seluruh perhitungan input-input faktor produksi Nilai Produksi Marginal (NPM) adalah sebagai berikut:

\section{$\mathrm{EH}=\underline{\mathrm{NPMX}}_{1} \underline{\mathrm{NPMX}}_{4}+\underline{\mathrm{NPMX}}_{3} \underline{\mathrm{NPMX}}_{4}$ \\ $E H=\underline{0.20+0.90+0+0.40}=0.38$}

\section{Efisiensi Ekonomi (EE)}

Perhitungan efisiensi ekonomi dapat dicapai apabila efisiensi teknis dan efisiensi harga telah diketahui dapat dihitung sebagai berikut:

$$
\begin{aligned}
& \mathrm{EE}=\mathrm{ET} \times \mathrm{EH} \\
& \mathrm{EE}=0.94 \times 0.38=0.35
\end{aligned}
$$

\section{Return To Scale (RTS)}

Hasil penjumlahan seluruh koefisien variabel produksi dapat diperoleh nilai return to scale sebesar 1.61 lebih besar dari 1 maka skala produksi industri pengolahan mengalami kondisi increasing return to scale.

\section{PEMBAHASAN}

\section{Intrepetasi Hasil Pengukuran}

Berdasarkan hasil regresi fungsi produksi pada Tabel 1 menunjukkan koefisien variabel memiliki pengaruh positif dan signifikan terhadap output produksi industri pengolahan.

Hasil estimasi efisiensi Tabel 3 masing-masing variabel secara proposional dapat mengalisis faktor-faktor produksi sehingga dapat memaksimalkan tingkat efisiensi dalam penggunaan masingmasing variabel yang mempengaruhi output produksi industri pengolahan.

\section{Penggunaan Modal Produksi (K)} Terhadap Output Produksi Industri Pengolahan dan Efisiensi Produksi

Berdasarkan Tabel 1 hasil regresi nilai t-hitung sebesar 5,25 lebih besar dari t-tabel yaitu 1,6523 dan nilai probabilitas sebesar 0,0000 lebih kecil dari nilai 0,05 ( $\alpha$ $=5 \%$ ) sehingga memiliki pengaruh positif dan signifikan terhadap output produksi industri pengolahan.

Efisiensi produksi pada Tabel 3 diperoleh koefisien regresi modal produksi $\left(\mathrm{X}_{1}\right)$ sebesar 0.17. Hal ini menunjukkan bahwa peningkatan penggunaan modal produksi dapat memberikan peluang kepada industri pengolahan untuk meningkatkan produksi karena semakin banyak hasil produksi maka proses produksi akan semakin besar.

Penggunaan Bahan Baku Produksi (B) Terhadap Output Produksi Industri Pengolahan dan Efisiensi Produksi

Berdasarkan Tabel 1 hasil regresi nilai t-hitung sebesar 24,45 lebih besar dari t-tabel yaitu 1,6523 dan nilai probabilitas sebesar 0,0000 lebih kecil dari nilai 0,05 ( $\alpha$ $=5 \%$ ) sehingga memiliki pengaruh positif dan signifikan terhadap output produksi industri pengolahan.

Efisiensi produksi pada Tabel 3 diperoleh koefisien regresi bahan baku produksi $\left(\mathrm{X}_{2}\right)$ sebesar 0.87. Hal ini menunjukkan jika terjadi peningkatan penggunaan bahan baku produksi industri akan terjadi peningkatan dalam proses produksi industri pengolahan. 
Penggunaan Tenaga Kerja Produksi (L) Terhadap Output Produksi Industri Pengolahan dan Efisiensi Produksi

Berdasarkan Tabel 1 hasil regresi nilai t-hitung sebesar 6.18 lebih besar dari t-tabel yaitu 1,6523 dan nilai probabilitas sebesar 0,0000 lebih kecil dari nilai 0,05 ( $\alpha$ $=5 \%$ ) sehingga memiliki pengaruh positif dan signifikan terhadap output produksi industri pengolahan.

Efisiensi produksi pada Tabel 3 diperoleh koefisien regresi tenaga kerja $\left(\mathrm{X}_{3}\right)$ sebesar 0.14. Hal ini menunjukkan apabila terjadi peningkatan tenaga kerja dalam proses produksi maka akan menaikkan output produksi industri.

\section{Penggunaan Upah Per Tenaga Kerja Produksi (U) Terhadap Output Produksi Industri Pengolahan dan Efisiensi Produksi}

Berdasarkan Tabel 1 hasil regresi nilai t-hitung sebesar 13,53 lebih besar dari t-tabel yaitu 1,6523 dan nilai probabilitas sebesar 0,0000 lebih kecil dari nilai 0,05 ( $\alpha$ $=5 \%$ ) sehingga memiliki pengaruh positif dan signifikan terhadap output produksi industri pengolahan.

Efisiensi produksi pada Tabel 3 diperoleh koefisien regresi upah per tenaga kerja produksi $\left(\mathrm{X}_{4}\right)$ sebesar 0.35 . Hal ini menunjukkan bahwa semakin bertambah upah per tenaga kerja produksi akan menaikkan produksi industri pengolahan.

\section{Efisiensi Teknis}

Berdasarkan Tabel 3 menunjukkan bahwa penggunaan faktor-faktor produksi industri pengolahan tidak efisien secara teknis sehingga perlu dilakukan penambahan input-input produksi yang lain agar memperoleh nilai tingkat efisiensi teknis 1 (satu).

\section{Efisiensi Harga}

Berdasarkan Tabel 3 menunjukkan bahwa penggunaan faktor-faktor produksi industri pengolahan tidak efisien secara harga sebab nilai tingkat efisiensi harga kurang dari 1 (satu) sehingga perlu dilakukan penambahan input produksi agar efisiensi harga tercapai dan memberikan keuntungan yang maksimal dalam proses produksi industri pengolahan.

\section{Efisiensi Ekonomi}

Berdasarkan Tabel 3 menunjukkan bahwa penggunaan faktor-faktor produksi industri pengolahan tidak efisien secara ekonomi sebab kurang dari 1 sehingga perlu dilakukan pencapaian efisiensi teknis dan efisiensi harga.

Efisiensi ekonomi tercapai apabila penggunaan faktor-faktor produksi digunakan secara optimal dalam proses produksi industri pengolahan.

\section{Return to scale}

Berdasarkan Tabel 3 menunjukkan bahwa dalam kondisi increasing return to scale maka hasil produksi industri pengolahan mempunyai peluang untuk meningkatkan output produksi dengan menambah faktor produksi secara optimal.

\section{PENUTUP \\ Kesimpulan}

Peningkatan pertumbuhan ekonomi regional dan kesejahteraan masyarakat yang merata maka sangat penting dalam peningkatan: a. hasil produksi industri pengolahan (manufaktur) dengan penggunaan faktor-faktor produksi lebih efisien; b. penambahan faktor-faktor produksi harus dilakukan secara proporsional untuk mencapai skala hasil yang lebih baik; c. permodalan dalam proses produksi untuk peremajaan mesin-mesin atau perkembangan teknologi yang lebih canggih sehingga meningkatkan produksi dalam berinovasi dan kualitas SDM dalam jangka pendek melalui pelatihan teknis maupun jangka panjang dengan pendidikan formal.

Perekonomian regional bersifat padat karya (labor intensive) maka untuk mendorong pertumbuhan regional diprioritaskan pada kegiatan industri-industri yang menyerap banyak tenaga kerja. Pengembangan industri padat karya seharusnya dilakukan dalam rentang waktu 
yang panjang dan berkelanjutan karena di daerah-daerah memiliki jumlah tenaga kerja yang banyak dan terus meningkat. Selain meningkatkan pertumbuhan ekonomi regional, pemerataan pembangunan juga menjadi perhatian pemerintah dalam meningkatan kerjasama antar daerah sehingga dapat mendorong potensi unggulan dari masing-masing daerah untuk menciptakan nilai tambah ekonomi yaitu dengan terkonsentrasinya industri atau aglomerasi industri pengolahan (тапиfaktur).

\section{Saran}

Berdasarkan pembahasan dan kesimpulan penelitian dapat disarankan bahwa perekonomian regional bersifat padat karya (labor intensive) maka untuk mendorong pertumbuhan regional diprioritaskan pada kegiatan industri-industri yang menyerap banyak tenaga kerja. Pengembangan industri padat karya seharusnya dilakukan dalam rentang waktu yang panjang dan berkelanjutan karena di daerah-daerah memiliki jumlah tenaga kerja yang banyak dan terus meningkat.

Selain meningkatkan pertumbuhan ekonomi regional, pemerataan pembangunan juga menjadi perhatian pemerintah dalam meningkatan kerjasama antar daerah sehingga dapat mendorong potensi unggulan dari masing-masing daerah untuk menciptakan nilai tambah ekonomi yaitu dengan terkonsentrasinya industri atau aglomerasi industri pengolahan (manufaktur).

\section{DAFTAR PUSTAKA}

Arsyad, L. (2010). Ekonomi Pembangunan. Yogyakarta: BPFE.

Jhingan, M. L. (2008). Ekonomi Pembangunan dan Perencanaan. Jakarta: PT. Raja Grafindo Persada.

Kholmi, M. (2003). Akuntasi Biaya. Edisi Empat. Yogyakarta: BPFE.
Kuncoro, M. (2012). Ekonomika Aglomerasi Dinamika \& Dimensi Spasial Kluster Industri Indonesia. Yogyakarta: UPP STIM YKPN.

Riyanto, B. (2001). Dasar-dasar Pembelajaran Perusahaan. Edisi Keempat. Cetakan Ketujuh. Yogyakarta: BPFE.

Riyardi, A. (2015). Analisis Fungsi Produksi Frontier Constant Elasticity Substitution Industri Makanan Hingga Pakaian Jadi di Provinsi Jawa Tengah. Universitas Muhammadiyah Surakarta. University Research Colloquium 2015 ISSN 2407-9189.

Simanjuntak, P. (2011). Manajemen dan Evaluasi kinerja. Jakarta: Fakultas Ekonomi UI.

Soekartawi. (2003). Teori Ekonomi Produksi,dengan Pokok Bahasan Analisis Fungsi Cobb-Douglas. Statistical Society A120.

Sjafrizal. (2008). Ekonomi Regional, Teori dan Aplikasi. Padang: Baduose Media.

Suyanto. (2012). Pertumbuhan Produktivitas Perusahaan Manufaktur Indonesia dan Penanaman Modal Asing: Penerapan Metode Dekomposisi. Fakultas Bisnis Dan Ekonomi Universitas Surabaya. Jurnal Ekonomi Pembangunan, 13(1), 162181.

Romdhoni, A.H. (2015). Analisis Fungsi Produksi Frontier Constant Elasticity Substitution Industri Makanan Hingga Pakaian Jadi Di Provinsi Jawa Tengah.

Riyardi, A. (2015). Analisis Fungsi Produksi Frontier Constant Elasticity Substitution Industri Makanan Hingga Pakaian Jadi di Provinsi Jawa Tengah. Universitas Muhammadiyah Surakarta. University Research Colloquium 2015 ISSN 2407-9189. 